\title{
FROM COURT CHAPEL TO PUBLIC CONCERT: HASSE'S ORATORIOS FROM DRESDEN TO VIENNA ${ }^{1}$
}

In the early 1770s Johann Adolf Hasse proposed two of his oratorios, originally conceived decades earlier, for the Court Chapel of King August III in Dresden, as productions of the Wiener Tonkünstlersozietät, a society for the support of musicians' widows, founded in 1771 by Florian Leopold Gassmann. They were meant to be performed at the Kärntnertortheater in Vienna in the same series of concerts which would have hosted Haydn's first oratorio, Il ritorno di Tobia. In order to fulfil this commitment, Hasse even postponed his long-cherished plans to move to Venice together with his family for six months. He accepted that proposal coming directly from count Johann Wenzel Sporck, "Musique Cavalier und General-Direktor" of the court theaters, in the following mood:

"Con tutto che come forestiero, e che è alla vigilia di lasciar il paese, io non ci entro per niente, si ha desiderato un oratorio da me. S. E. Conte Sporc me lo propose dunque mesi sono come un'opera pia, e da farsi gratis, titolo, con cui era impossibile il ricusarlo, massime in paese ove ho avuto del bene; siché l'accettai senz'altro, e lo faccio anche volentieri."

While accepting to work for this charitable enterprise, Il Sassone, who had just completed his fifty-year career as opera composer in Milan, in October 1771, was presenting once more an oratorio in the town where he had performed forty

1 I dedicate this article to the memory of Sven Hansell, the outstanding American researcher Hasse studies are so much indebted to, who passed away on 6 March 2014.

2 "Even if I am a stranger, I am nearly leaving the country and I have nothing to do with it, they asked from me an oratorio. His excellence Count Spork proposed it to me some months ago as a pious deed, with no earning; in such a way I could not avoid to accept, especially in a country where I have been benefited from; I therefore accepted immediately, and I am writing it with pleasure." Letter to Giovanni Maria Ortes, 24 October 1772. Hasse's letters will be quoted directly from the autographs kept at Museo Correr in Venice. Hasse's statement corresponds with the pious remark "Laus Deo, et Beatæ Mariæ semper Virgini", written by the composer at the end of the autograph score of the second oratorio of this series, Il cantico de' tre fanciulli (I-Mc, MUSA. MS. 135.3, II, p. 175). 
years earlier, on February 15 1731, his very first one, Il Daniello, ${ }^{3}$ on an original text written for that occasion by Apostolo Zeno, who had committed himself to sending annually an oratorio to Vienna after leaving the Imperial Court in $1729 .{ }^{4}$ Mature Hasse, however, did not choose to write new works, nor did he go back to his Viennese Daniello, but rather chose to revise at first one, and then another oratorio from the conspicuous series of eight he had written for the Dresden Court during little more than fifteen years, from 1734 to 1750 . Specifically he chose to revise the scores of Sant'Elena al Calvario first, and then of Il cantico de'tre fanciulli, adapting them from their original destination to the new one (Tab. 1).

\section{Sant'Elena al Calvario}

Dresden, Court Chapel, 9 April 1746 Vienna, Kärntnertortheater, 17 December 1772

Il cantico de' tre fanciulli

Dresden, Court Chapel, 24 April 1734 Vienna Kärntnertortheater, 18 December 1774

Tab. 1. Hasse's Oratorios from Dresden to Vienna

Sant'Elena was performed on 17 and 20 December 1772 at the Kärntnertortheater, conducted by Hasse himself, in what turned out to be a triumph, as Hasse commented after the premiere:

"Il mio oratorio fu prodotto giovedi scorso, e posso dire senz'offendere la verità, ch'ebbe un incontro si pieno, che da grand'anni in qua non mi ricordo aver fatto una cosa, che abbia sortito un esito si felice. Iddio, ch'è sempre misericordioso, e da cui riconosco tutto, senz'attribuir nulla alla meschinissime mie forze, si è degnato di animare, e di confortar questa volta il mio talento e spirito d'una maniera particolare, perché appunto avevo accettato, ed intrapreso un'opera sacra, e pia. Siché, se anche nell'età in cui mi trovo non faccio altro, ho la consolazione di aver finito bene. Non ho però mai fatto una funzione più grandiosa, mentre fra sonatori, cantanti, $e$ coristi, ho avuto un complesso di 180 esecutori; e conviene, che faccia giustizia ad ogn'uno, essendo stato eccellentemente ben servito da tutti."

3 There is no reason to doubt about the authenticity of Daniello: for a discussion of this case, as well as general information on Hasse's life and output, see MELLACE, Raffaele. Johann Adolf Hasse. Palermo: L'Epos, 2004, p. 393-395 (German translation by Ortus-Verlag Berlin forthcoming).

4 See ZENO, Apostolo. Epistolario scelto di Apostolo Zeno veneziano. Venice: Alvisopoli, 1829 , p. XIII.

5 "My oratorio has been performed last Thursday and I can say without going against the truth that it has been so successful that I cannot remember to have done anything that has been so successful for many years. So, even if in my age I write nothing more, I should be happy, since I ended well. I never had a grander performance, since I had in the whole, among instrumentalists, singers and choir, 180 performers, and they all did an excellent job for me." Letter to Giovanni Maria Ortes, 19 December 1772. 
The circumstance is confirmed by the press announcement of the second performance of the oratorio:

"Heute Sonntags am 20. Kristmonats 1772 wird in dem k. k. priv. Schauspielhause nächst dem Kärtnerthor auf Verlangen zum zweiten- und letztenmal Eine Grosse musikalische Akademie gehalten werden, wobey das am 17. d. M. gehaltene Oratorium von 5 Stimmen des berühmten H. Abbts Peter Metastasio gesungen wird, genannt die heilige Helena auf dem Calvarienberge. Die Musik, welche Sänger und die übrigen Instrumente zusammengenommen aus mehr denn 180 Personen besteht, ist von eben dem sehr berühmten H. Hasse Hofcapellmeister am chursächsischen Hofe ganz neu dazu verfertigt worden. [...] Zwischen beyden Abteilungen des Oratoriums wird sich Herr Küffel auf dem Violoncello hören lassen. - Die Eintrittspreise sind wie bei den Opern-Serien [...]. Die Anfang ist mit dem Schlag 7 Uhr." 6

As he moved to Venice, Hasse sticked to his engagement with the Tonkünstlersozietät: his revised version of Il cantico de' tre fanciulli was sent to Vienna to be performed on December 181774.

These works have been researched in a distant or more recent past by Łucjan Kamieński, Michael Koch, Alberto Viarengo, Anna Ryszka-Komarnicka, John Rice and myself. ${ }^{7}$ Moreover, this journal hosts an article by Elizabeth Fritz on the oratorios produced by the Tonkünstlersozietät. I will try to enquire the peculiar status of these works, which Hasse's revision converted to a different destination, for a different public, different performers and a different venue. This particular case of a revision operated directly by the author himself shows very clearly the potential of metamorphosis of oratorio as a genre permanently positioned between church and theatre, court and town.

6 The news have been first published by Eduard Hanslick in his Geschichte des Concertwesen in Wien (Wien: Braumüller, 1869, I, p. 30) and later quoted by KAMIEŃSKI, Łucjan. Die Oratorien von Johann Adolf Hasse. Leipzig: Breitkopf und Härtel, 1912, p. 166-167. A similar bilingual Theaterzettel has been published in RICE, John A. Hasse's Viennese Settings of Sant'Elena al Calvario and the Tonkünstler-Sozietät Oratorio of the 1770s. In Johann Adolf Hasse in seiner Zeit. Bericht über das Symposium vom 23. bis 26. März 1999 in Hamburg, ed. by R. Wiesend. Stuttgart: Carus-Verlag, 2006, p. 261-272: 272.

See KAMIEŃSKI, op. cit., p. 180-191; KOCH, Michael. Die Oratorien Johann Adolf Hasses: Überlieferung und Struktur. Pfaffenweiler: Centaurus, 1989, passim; VIARENGO, Alberto. L'oratorio "Il cantico de "tre fanciulli" di Johann Adolf Hasse: inquadramento storico, analisi; edizione critica. Diss. Univ. di Pavia, 1990/91; RYSZKA-KOMARNICKA, Anna. Johann Adolf Hasse e Pasquale Anfossi: "Sant'Elena al Calvario": tentativo di analisi comparativa. In Johann Adolf Hasse in seiner Epoche und in der Gegenwart. Studien zur Stil- und Quellenproblematik, ed. by Szymon Paczkowski and Alina Żórawska-Witkowska. Warszawa: Instytut Muzykologii Uniwersytetu Warszawskiego, 2002, p. 139-154; RICE, op. cit.; MELLACE, Raffaele. Metastasio, Hasse e "Sant'Elena al Calvario": poesia e musica tra attesa e miracolo. In Drammaturgia dell'oratorio. Metastasio, Hasse e il caso di "Sant'Elena al Calvario". Atti della giornata di studi musicologici, Faenza, 14 maggio 2005, ed. by Giovanni Tasso. Cesena: Edizioni Musigramma, 2006, p. 13-29. 


\section{Continuity of a Courtly Experience?}

It could be actually stated that Hasse's oratorios produced in Vienna express the continuity of courtly experience. The genesis and nature of these works are clearly conveyed by the front page of the original Dresden librettos, such as this: "Sant'Elena / al / Calvario. / Oratorio / da cantarsi / nella / Regia Elettoral / Cappella di Dresda / Il Sabato Santo. / Nell'anno MDCCXLVI." Sant'Elena and Il cantico are both based on oratorio texts written in the early 1730s for centralEuropean courts. Sant'Elena was Metastasio's second oratorio commissioned by the imperial court in Vienna for the Holy Week 1731 (the same year Hasse's Daniello was performed in Vienna), as the ruling emperor was still Charles VI, who had hired the poet the year before. ${ }^{9}$ The original musical setting was provided by vice-Kapellmeister Antonio Caldara; Hasse set the text fifteen years later. Il cantico was on the other hand Hasse's first oratorio for Dresden in 1734, the year when he actually started his duty as Kapellmeister after the death of king August II and the appointment of the new king and elector, Hasse's patron August III. In that case, the composer had the chance to set a brand-new text provided by court poet Stefano Benedetto Pallavicino. The Italian poet, 62 by then, was born in 1672 , and belonged therefore to the generation prior to Hasse's and Metastasio's. He had been hired as Court poet in Dresden still as a teenager in 1688 (by then he was already working on his first libretto, Antiope, meant for his father, the famous opera composer Carlo Pallavicino, but set by Nicolaus Adam Strungk as Carlo suddenly died), an entire decade before Hasse and Metastasio were born, but returned to Dresden much later, in 1719, and experienced a new and very prolific late season of his long career with Hasse's arrival at the Saxon court. ${ }^{10} \mathrm{Il}$ cantico is the first of a set of three oratorios written by Pallavicino between 1734 and 1742, the year of the poet's death, including Le virtì appiè della croce and the conspicuous I pellegrini al Santo Sepolcro, one of the most popular oratorios in the whole 18 century. Both texts are therefore by professional playwrights who reached the top of their careers by the time they worked at these texts, with the appointment as court poets in two of Europe's most important courts. Not only the authors of the texts, but the command of the oratorios itself cannot be separated from the frame of courtly life: in both cases those oratorios constituted the main musical-devotional activity of the Holy Week, the year's most important celebrations for the Catholic Church.

8 I quote the copy belonging to the Staatsbibliothek zu Berlin - Preußischer Kulturbesitz, Musikabteilung mit Mendelssohn-Archiv (Mus. Th. 269/3). I am grateful to the library and to the kindness of Dr. Roland Schmidt-Hensel.

9 On Metastasio's text see METASTASIO, Pietro. Oratori sacri, ed. by Sabrina Stroppa. Venice: Marsilio, 1996, p. 239-245; STROPPA, Sabrina. «Fra notturni sereni». Le azioni sacre del Metastasio. Florence: Olschki, 1993; BELLINA, Anna Laura. La madre di Costantino, la vedova di Manasse e la nonna di Gioas. In Drammaturgia dell'oratorio, op. cit., p. 31-40.

10 See MELLACE, Raffaele. Article "Stefano Benedetto Pallavicino". In Dizionario Biografico degli Italiani, LXXVIII, forthcoming. 
If the original occasion of both oratorios belonged to courtly life, the imperial court was involved, although on a different level, also in supporting the production of the Tonkünstlersozietät oratorios under Joseph II, much distant as he was from his grandfather Charles VI. The support for the charitable activities of the Tonkünstlersozietät must be seen as a deliberate move by the emperor to supply some relief to the state's budget, entrusting that charitable society with the support of the musicians' widows and orphans. Moreover, the court's musical establishment was directly involved in the Tonkünstlersozietät oratorio production, as it can be proved through an interesting letter by Hasse to Antonio Salieri concerning the production of Il cantico. Since Hasse had moved to Venice in April 1773, the oratorio for the following year's Advent season had to be entrusted to local musicians. The choice was made of the highest possible rank: Il cantico was conducted by Giuseppe Bonno (himself composer of an oratorio for the Tonkünstlersozietät for Lent 1774), who had succeeded Gassmann both as imperial Hofkapellmeister and in the direction and then presidency of the Tonkünstlersozietät. In his duty, Bonno was assisted by Antonio Salieri who would succeed him as imperial Hofkapellmeister and who had a major role in the production of the oratorio by Hasse, training the singers for the Viennese performance, apparently attended by the emperor himself. ${ }^{11}$ Hasse had most certainly got to know older Bonno half a century before, back in the 1720s, in Naples, where Bonno had been studying for an entire decade (1726-1736). The acquaintance with Salieri occurred much later, when the younger colleague reached Vienna in $1766 .{ }^{12}$ On January 71775 Hasse answered a letter by Salieri with a hitherto unpublished letter, ${ }^{13}$ quite informative about the Viennese Cantico production:

"Stim:"mo ed amatiss:"mo mio Sig:" Salieri,

La gentil:"ma , e cordialiss: ${ }^{\text {ma }}$ Sua de' $22 X^{\text {bre }}$ m'empie di consolazione non meno che di confusione, per le troppe generose ed affettuose espressioni, colle quali Ella si degna di honorare il tenue mio merito. Comunque si sia, non posso non essere sommamente sensibile alle notizie felici che mi dà del mio oratorio, il quale, essendo stato prodotto da un'armonica società si rispettabile, e diretto dal si virtuoso Sig:r Maestro Bono, mio antico buon prone [padrone] ed amico, non poteva che sortir un buon esito. So poi in particolare con quant'amorosa bontà Ella si è compiaciuta di

11 Joseph was an old acquaintance of Hasse, who not only had composed the feste for Joseph's 1760 marriage (Alcide al bivio) and his election as emperor (Egeria, 1764), but in 1762 had performed with him and the entire imperial family (Hasse and Joseph played each an organ, the empress and the other children sang) in the Litanie in the St. Augustin church in Vienna (see MELLACE, Raffaele. L'autunno del Metastasio. Gli ultimi drammi per musica di Johann Adolf Hasse. Florence: Olschki, 2007, p. 111-121, 211-227 and MELLACE, Raffaele. Johann Adolf Hasse, op. cit., p. 373-375).

12 Young Salieri had been welcomed in Vienna in Hasse's name: later on the Italian composer recalled singing in a private after-dinner concert for Joseph II the alto part from some choruses and arias from Hasse's just quoted Alcide al bivio (see HEARTZ, Daniel. Haydn, Mozart and the Viennese School. 1740-1780. New York-London: W.W. Norton, 1995, p. 424).

13 The letter, today in the Mary Flagler Cary Music Collection of the Pierpont Morgan Library in New York (MFC H354.S165) will be published in its entirety in the forthcoming German edition of MELLACE, Raffaele. Johann Adolf Hasse. 
cooperare, perché ogni cosa vada con buon ordine, e quanta cura e pena si è presa nel comunicar a' cantanti i miei sentimenti; e come so tutto questo distintam: ${ }^{\text {te }}$, e con quant 'amicizia ha voluto in tal occasione operare per me, così non mancherò mai di professargliene ogni più dovuta gratitudine ed obbligazione. Rimango poi ben rispettosam: ${ }^{\text {te }}$ incantato della somma clemenza di cotesto illuminatissimo Monarca, e del clementiss: ${ }^{\text {mo }}$ compatimento che la M: ${ }^{a}$ Sua s'è degnata di donar alle povere mie fatiche; e giaché di più, com'Ella mene assicura, anche cotesto si rispettabile publico n'è rimasto contento, cosi ringraziamo, e diamone gloria e lode all'Altissimo, [uni]co, e vero Datore d'ogni Bene, Padre, e Protettore delle Vedove [...]."14

Hasse's courtly oratorios had already been transferred to a bourgeois environment a decade earlier, in Leipzig, where Johann Adam Hiller had been promoting from the early 1760s, in his position as artistic director of the Großes Konzert, and then as Kapellmeister of the Gewandhaus concerts, a historically relevant series of Hasse performances in Leipzig. He organized concert performances of operas and feste teatrali, but most of all the oratorio productions: no less than 12 performances between 1763 and 1772. A performance of Sant'Elena, in the original Dresden version, in December 1767 (the oratorio was performed twice, with Dorothea Schröter as Elena; it had been already heard in Leipzig earlier that year, on Monday and Wednesday in the Holy week) ${ }^{15}$ was attended by young Goethe, who still decades later recalled the vivid impact left in his mind by some of the arias. ${ }^{16}$ Hiller had been even promoting the publication of single pieces from Hasse's oratorios since $1767 .{ }^{17}$

14 "Most estimated and dearest Mr. Salieri, Your kindest and dearest letter of December the $22^{\text {th }}$ gives me so much pleasure and confounds me for the far too generous and dear expressions you decided to honour my small merit with. Anyway, I cannot be if not extremely sensitive to the good news you give me of my oratorio, which, being produced by such a honorable harmonic society and conducted by the so talented Maestro Bonno, good old lord and friend of mine, couldn't avoid being successful. Moreover, I especially know what caring efforts you personally made to contribute so that everything went in the right way, and how much care and effort you put in passing the singers my wishes; since I know how excellently and friendly you acted at my advantage in that occasion, I will never avoid to profess you all my gratitude and obligation. I also remain respectfully enchanted by the utmost clemency of this most enlightened sovereign [Joseph II] and of the most clement endurance which His Majesty deigned to reserve to my poor efforts, and since moreover, as you assure me, this so respectable audience has been satisfied, we should thank and give glory and praise to the Highest, only and true Giver of every good, Father and widows' Patron."

15 See GRENSER, Carl August. Geschichte der Musik hauptsächlich aber des großen Conzer$u$. Theater-Orchesters in Leipzig (1840), ed. by Otto Werner Förster. Leipzig: Taurus Verlag, 2005, p. 20-21. A chorus from Sant'Elena was still performed in the Gewandhaus New Year concert in 1811 (p. 107).

16 See OTTENBERG, Hans-Günter. Vom „Weltbürger“ zum Komponisten, der „den Kunstgesetzen seiner nordischen Heimath untreu“" wurde. Hasse-Studien, 2012, n. 7, p. 91-111: 104-105.

17 Three items from Sant'Elena appeared in Wochentlichen Nachrichten in 1767, a chorus in Meisterstücke des italiänischen Gesanges, in Arien, Duetten und Chöre, published mit deutschen geistlichen Texten, in 1791 in Leipzig, by Johann Friedrich Junius (see Répertoire international des sources musicales. Einzeldrucke vor 1800, A/I/4, ed. By K. Schlager. Kassel: Bärenreiter, 1974, H 2237 e H 2273). 


\section{Hasse's Music: from Devotional Intimacy to Spectacular Grandness}

It must be remarked beforehand that, in writing for the Musikalische Akademie of the Tonkünstler-Societät, Hasse aimed more at updating the sound atmosphere of his older oratorios rather than radically transforming their expressive mood, which does not change dramatically. ${ }^{18}$ Since the oratorios were not meant anymore for the Court Chapel and its ordinary staff, no castrati were going to be exploited. As a consequence one of the roles, Draciliano from Sant'Elena, changed from alto to bass role. Not just the performers, but the place of the performance changed: no more the small, old Court chapel in the Elector's palace in Dresden (not yet the new Hofkirche, inaugurated only in 1751, for which Hasse wrote no oratorios), but the large room of a theatre which demanded different and louder sonorities. Hasse, who had been eager to think back at his own (mostly operatic) works for all of his life, was thus challenged to venture into very important and deep revisions. Such changes have been already discussed several times: ${ }^{19}$ I will therefore just synthetize them without concentrating on specific examples.

18 The autograph score of the Viennese version is kept at the Library of the Conservatorio "Giuseppe Verdi" in Milan (MUSA. MS. 138.6). The work has been first performed in modern times at the St. James Church in Hamburg on $26^{\text {th }}$ March 1999, when Michael Schneider conducted the Stagione Frankfurt and the Dresdner Kammerchor. I am grateful to Wolfgang Hochstein and the Hasse-Gesellschaft Bergedorf for letting me access to the NDR recording of the concert. The Dresden, original version of the oratorio has been checked on the manuscript score kept at the Bayerische Staatsbibliothek in Munich (Mus. Ms. 237), published in facsimile as n. 28 of the "The Italian Oratorio 1650-1800" (New York: Garland, 1987). The introduction by Joyce L. Johnson wrongly states the manuscript corresponds to the Viennese version. Being Hasse's autograph, as the one of the Dresden Cantico, lost, Michael Koch considers it a very reliable witness: "mutmaßlich letzte Fassung des Autographs". A part from some details, it corresponds to the Dresden manuscript D-Dlb 2477-D 20, belonging to the king's private library (see KOCH. Die Oratorien Johann Adolf Hasses, I, p. 87 and II, pp. 81-85, 109-112 and LANDMANN, Ortrun in Katalog der Dresdener Hasse-Musikhandschriften, CD-Rom, ed. by Ortrun Landmann. Munich: RISM-Arbeitsgruppe Deutschland, 1999). The work has been performed in modern times at the St. Augustin Church in Faenza on $14^{\text {th }}$ May 2005, when Ottavio Dantone conducted the Accademia Bizantina and the Stagione Armonica. I am grateful to Ottavio Dantone and Romano Valentini for letting me access to the private recording of the concert (none of Hasse's Sant'Elena is available as commercial recordings). The performance was coupled with a conference, whose proceedings have been published as Drammaturgia dell'oratorio cit. Il cantico de' tre fanciulli might be read in its original 1734 Dresden version in the manuscript from the Dresden Library (D-Dl Mus. 2477-D-8) or in the copy kept in the Musiksammlung der Österreichischen Nationalbibliothek (A-Wn S.M. 1047). As it is the case with Sant'Elena, we fortunately own Hasse's autograph of the later Viennese version, kept in the composer's personal library, since 1815 in Conservatorio "Giuseppe Verdi" in Milan (MUSA. MS. 135.3). Both versions of Il cantico are available as commercial recordings, the Dresden one performed by Camerata Fulda and the Kammerchor des Theresiengymnasiums München conducted by Harald Kraus (2000, Koch Classics 3-6587-2); the viennese version by Ensemble Musica Rara and the Ars Cantica Choir, conducted by late Arnold Bosman (2001, Bongiovanni Bologna, GB 2283/84-2). 
In these new versions, overtures open each part of both oratorios; these instrumental introductions are now much longer and in Italian style. Choruses grow in importance and gain newly composed, extended choral fugues. The weight and extent of accompagnati grow significantly (Elena's first allocution, "Fortunato terreno", is now set in accompagnato in Vienna, while her last recitativo gets deeply revised). Formally the arias differ much more than in the original versions. Some important arias are newly composed: this is what happens, for example, in Cantico, with the two arias for Anania, starting from the very first aria of the score, "Vago sole, onor del giorno". Hasse makes a masterpiece out of it, opening the aria with a long note as he had often done in his Salve regina, which recalls the long $\mathrm{F}_{4}$ played by the oboe inaugurating the oratorio's overture - an overture which had been conceived exactly forty years earlier. It is also worth considering Azaria's aria "Tutte all'invito", which had been conceived in Dresden for the concertante arch lute of virtuoso Silvius Leopold Weiss, and was radically revised in Vienna for a much heavier instrumentation meant for a bigger concert hall. A great number of details get moreover changed: changes which vary from the bare lengthening of some bars to the substitution of some sections altogether.

Orchestration is certainly a major point and concern in this revision process: the orchestra in Vienna was certainly much larger, closer to the classical-style standard orchestra, since it acquired trumpets, trombones, English horns, timpani; moreover, bassoons are employed autonomously. Hardly a single page retained its original orchestration. Sometimes the changes implied important consequences, occasionally obtained by introducing very subtle effects with concertante or concertino instruments. In Sant'Elena, for example, the aria "Del Calvario già sorger le cime" turns from the mood of an intimate pilgrimage to a powerful, nearly warlike pictorial description of apocalyptical events. Sometimes, however, the orchestration changes very little, as it happens in the case of the overture to Il Cantico, where a second oboe and the horns are added to barely reinforce the original oboe-solo-and-strings orchestration. Sometimes, as in the aria "In te s'affida" from Sant'Elena, the new orchestration (with pairs of flutes, English horns, horns and muted violins) aims to a very similar, comparable effect to the original one (with flutes and muted violins and violas). ${ }^{20}$ Orchestration had in fact been a major concern for Hasse already in Dresden: the Cantico had been the first major production in the new Kapellmeister's duty in early 1734, even before staging an opera, the first being the July Cajo Fabricio. No doubt $i l$ Sassone intended to show his ability of exploiting the talents of the King's celebrated orchestra, after the hors-d'œvre Cleofide production, dated three years earlier. Very tellingly, the list of contents of the Dresden manuscript of Il cantico highlights in red ink the instrumentation of each piece which exceeded the strings-only orchestration

compositional choices in the context of the Tonkünstler-Societät oratorios, see in particular RICE, op. cit., p. 263-271. 
(Tab. 2) ${ }^{21}$ Hasse's attitude in revising Il cantico was not in fact revolutionary: he rather made a step further on the path of a growingly sophisticated instrumental thought.

\begin{tabular}{|l|l|}
\hline Musical Item & Remark on instrumentation in D-DI Mus. 2477-D-8 \\
\hline Introduttione & con Oboe solo \\
\hline Già sale all'etere & con Corni \\
\hline Venticel che sovra i prati & con Flauti \\
\hline Tutte all'invito & con Arciliuto \\
\hline Notte amica, oblio de' mali & con Corni e Flauti \\
\hline Fonti che a sorso & con Corni \\
\hline La Grand'opra & con Oboi e Fagotto \\
\hline
\end{tabular}

Tab. 2. Instrumentation of the 1734 Dresden Cantico de 'tre fanciulli, as highlighted by a ms. in the Dresden Library (D-Dl Mus. 2477-D-8)

While Metastasio's Sant'Elena text was kept unaltered in Vienna, Il Cantico needed some structural intervention, since Pallavicino's text, although written already in the 1730s, had been conceived in the older form as a one-part-only oratorio, as it is also the case of the second oratorio Pallavicino wrote for Hasse, Le virtù appiè della croce. The intervention went in the direction of developing a new grandeur, first of all operating on the spot which was detected as a good end for the new Part 1 of the oratorio. The only aria sung by Nabucodonosorre, the Assyrian king pretending the conversion of the three Hebrew, whom he threatens with capital punishment (incidentally also the only aria in the entire oratorio sung by a male voice) was apparently deemed a suitable dramatic and musical turning point. Nabucodonosorre's aria was amplified by the intervention of the choir, which was given a string of clumsy, mostly quinari lines, not perfectly fit with Pallavicino's original elegant settenari text (Tab. 3). Hasse's autograph states exactly the precise intention of the choir's contribution, establishing that "Coro, ch'entra in cadenza coll'istesso tempo, e coll'istesso fuoco; e continua col medesimo furore sino al fine" ("the choir should enter on the cadence with the same tempo and fire, and continue with the same fury till the end"). ${ }^{22}$ The composer cared to provide the future conductor of the Viennese production (he presumably did not expect to conduct himself) with a caring remark on the same page of the autograph score: "si contenti chi dirige di avertir $i$ coristi per tempo" ("the conductor should remember to alert the singers from the choir on due time"). ${ }^{23}$

21 On Hasse's early operatic output in Dresden and on his systematic exploitation of the court orchestra see MELLACE, Johann Adolf Hasse, p. 237-239.

Ibid. 


\begin{tabular}{|c|c|}
\hline Dresden 1734 & Vienna 1774 \\
\hline $\begin{array}{l}\text { NABUCODONOSORRE } \\
\text { Perfidi, sì, morrete, } \\
\text { e con tremendo esempio } \\
\text { ardendo appagherete } \\
\text { autorità oltraggiata, } \\
\text { sprezzata deità. } \\
\text { Precipitati, olà, } \\
\text { viva d'inferno immagine, } \\
\text { gli assorba la voragine; } \\
\text { e desti il loro scempio } \\
\text { spavento e non pietà }\end{array}$ & 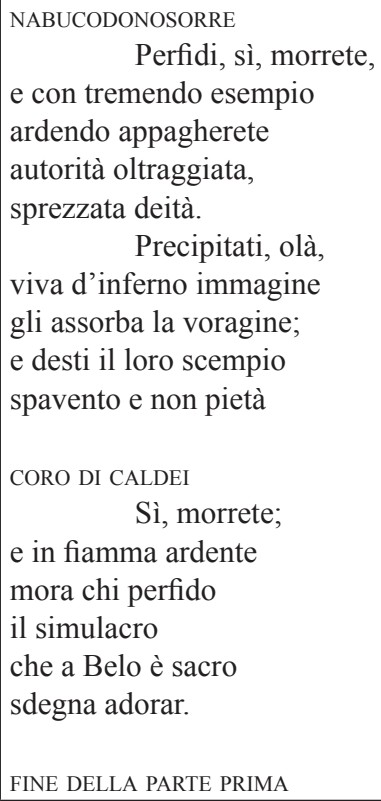 \\
\hline
\end{tabular}

Tab. 3. Nabucodonosorre's Aria: the Two Versions Compared

This spot had been already conceived as a turning point in the original version of the oratorio. The king's G minor aria was in fact followed by the Angel's Gmajor accompagnato "Amici, al Dio d'Abramo", introducing God's intervention in the story and marking a sharp distance between the king's menaces and the positive turn the plot is going to take. In the Viennese version, the opening of Part II of the oratorio required the addition of a new instrumental overture (which surprisingly fits perfectly with the overall original pastoral tone of the entire oratorio). As a consequence, the Angel's text did not require any more to be set as accompagnato and was recomposed as recitativo semplice (Tab. 4).

\begin{tabular}{|c|c|}
\hline Dresden 1734 & Vienna 1774 \\
\hline $\begin{array}{l}\text { - Nabucodonorre's Aria } \\
\text { - Angel's Recitativo Accompagnato }\end{array}$ & $\begin{array}{l}\text { - } \\
\text { - Chabucodonorre's Aria } \\
\text { End of Part I } \\
\text { - Overture II } \\
\text { - Angel's Recitativo Semplice }\end{array}$ \\
\hline
\end{tabular}

Tab. 4. Il cantico de' tre fanciulli: Two Solutions Compared 
Surprisingly, the original affections, the expressive niveau of the oratorios was not drastically influenced by the revision process. At least this is what happened, significantly, in the heart of these works: the wonderful string of arias originally conceived for the virtuoso singers of the king of Poland of the Dresden Court Chapel. More considerable changes in the mood of these works affected rather than the frame the heart of the two oratorios: those peripheral pieces - instrumental introductions and choruses - which were definitely marginal and fewer in number in the original version, but had tremendously grown in importance in the Viennese revision. Probably the most striking case might be observed comparing the two versions of the overture to Sant'Elena. Hasse's "Introduzzione" (sic) for Dresden opens on an E-flat minor dark and intimate introduction, which sets the atmosphere for the austere Lent devotion rite meant for the king and his court in the small Court Chapel (Ex. 1).

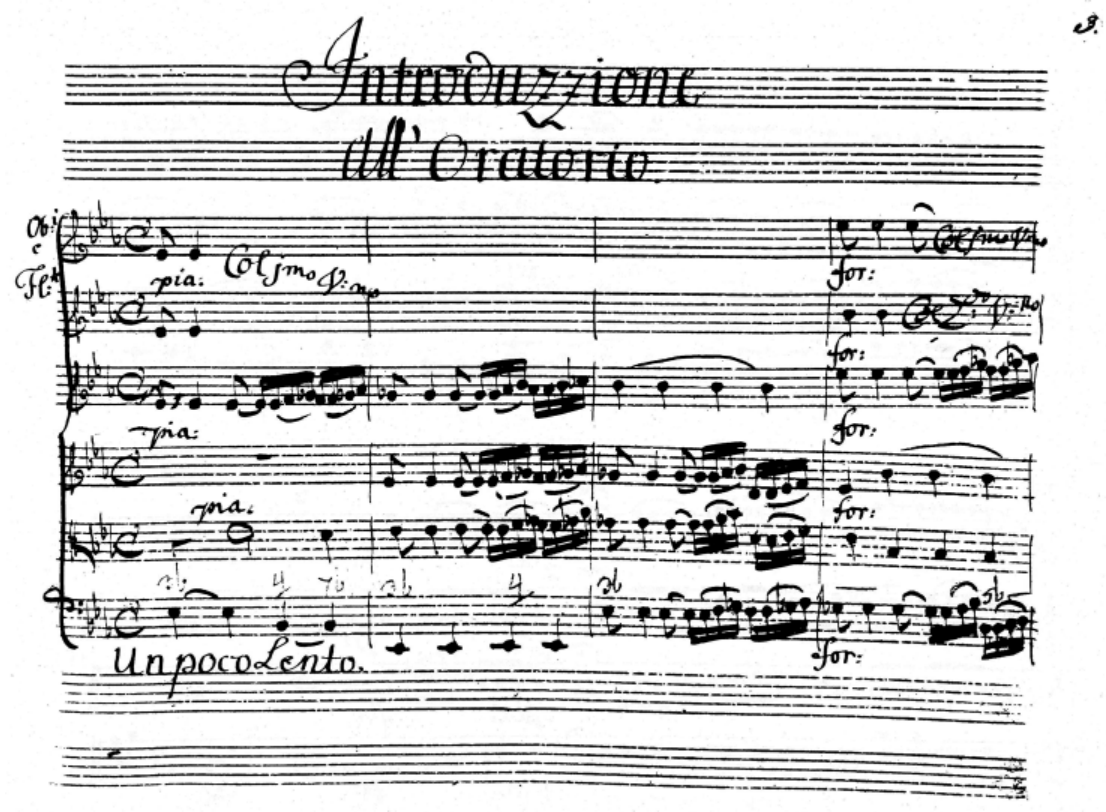

Ex. 1: Sant'Elena al Calvario (Dresden 1746). "Introduzzione"

On the other hand, the Viennese "Sinfonia" is a grand, dramatic C-minor symphonic overture, marked Allegro, e con spirito and scored for trumpets, timpani, horn, oboes and strings, much more appropriate to the fruition of a larger hall of a theatre (Ex. 2).

Although most of the revision process is strictly connected to practical grounds and does not alter the general mood or the main affection of both oratorios significantly, these few peripheral but conspicuous modifications, while probably not 


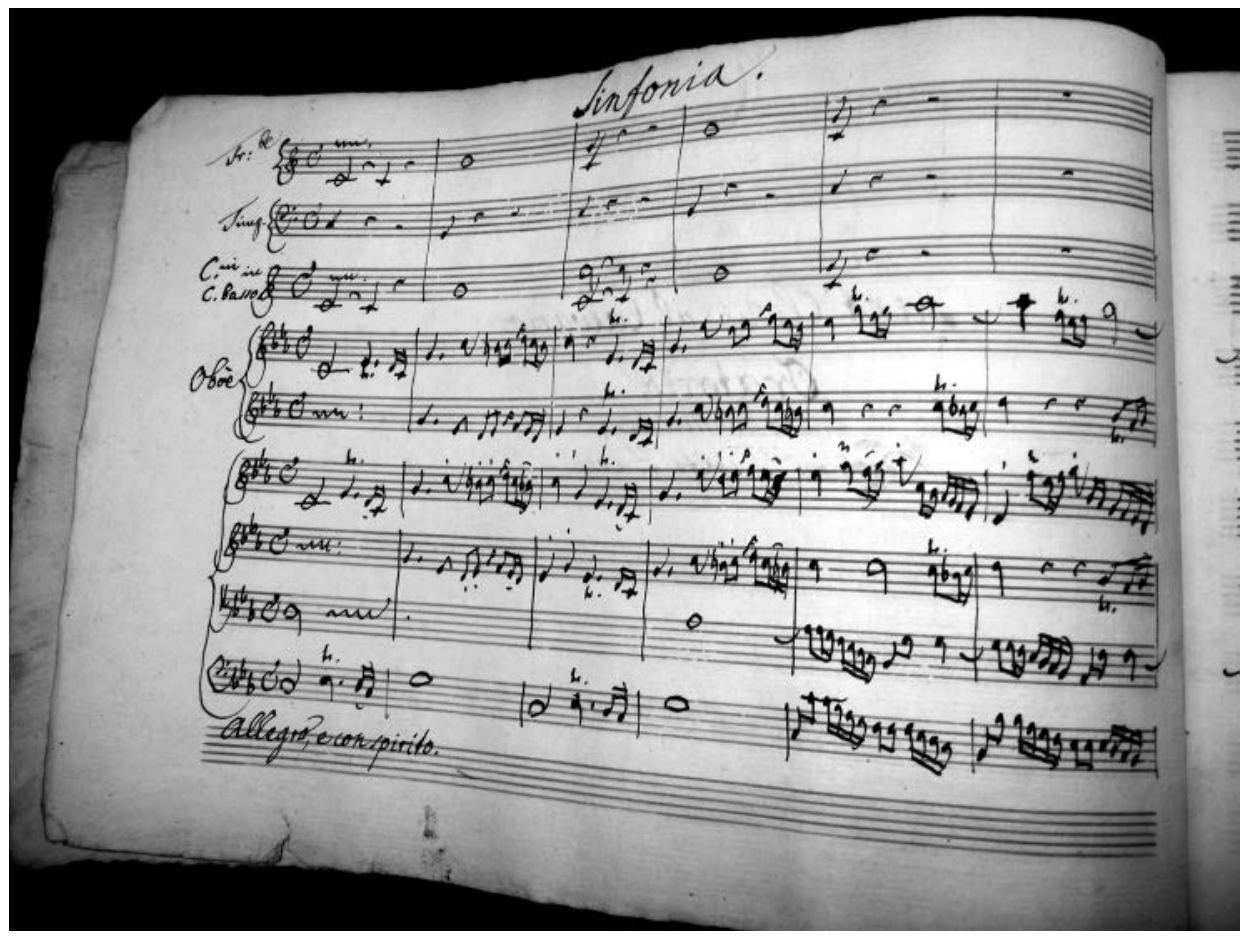

Ex. 2: Sant'Elena al Calvario (Vienna 1772). "Sinfonia"

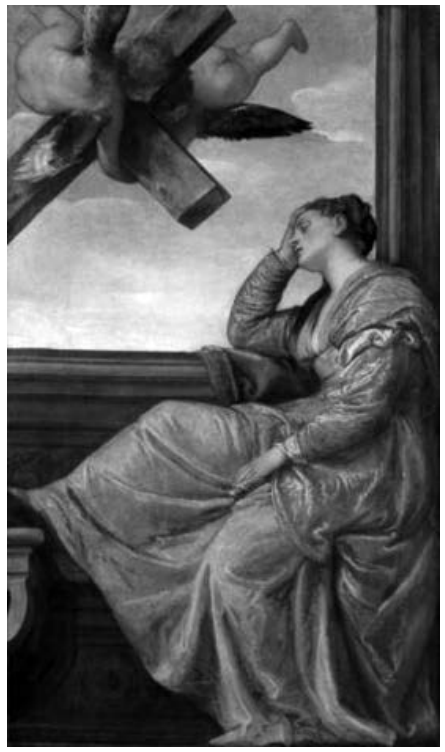

Fig. 1: Paolo Veronese, The Dream of Saint Helena, 1570 ca., London, National Gallery.

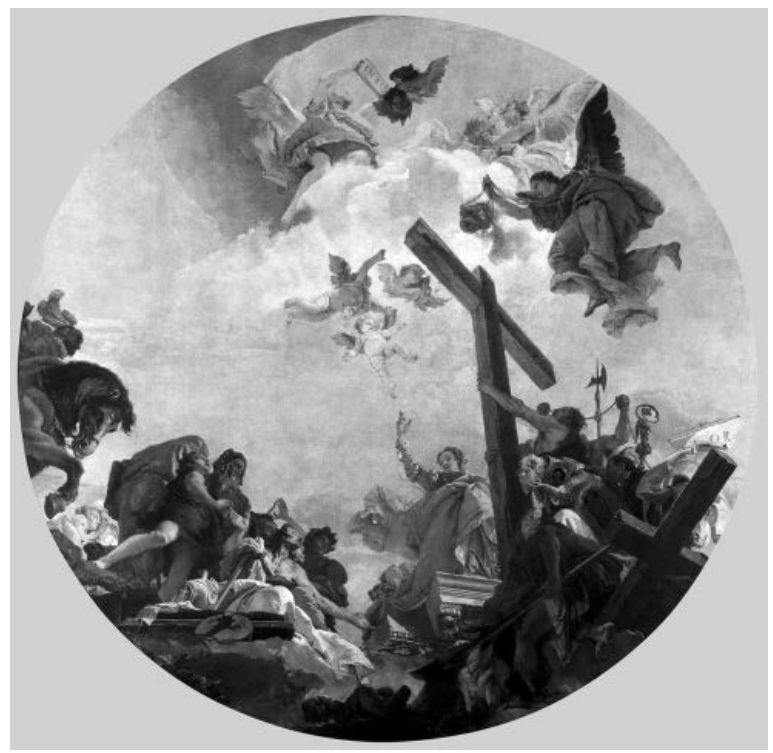

Fig. 2: Giambattista Tiepolo, The Discovery of the True Cross, $1745 \mathrm{ca}$., Venice, Gallerie dell'Accademia. 
able to convert radically the global message of the work, contribute to add a peculiar flavor which distinguishes the Viennese version from its Dresden model. This is what happens more clearly in Sant'Elena. The transformation of its overture does not just offer a new version of older music, but rather changes the listener's viewpoint on the holy story. One might compare these two different solutions with those pursued by two major Italian painters in their interpretation of the subject of Saint Helena. In The Dream of Saint Helena (1570 ca.; London, National Gallery) Paolo Veronese interprets the subject as an intimate pious meditation, depicting the true Cross appearing in dream to the empress (Fig. 1).

On the other hand, Giambattista Tiepolo chooses a much different moment in the holy story, showing rather the miracle of the Discovery of the True Cross (1745 ca.; Venice, Gallerie dell'Accademia) on the Golgotha, setting the episode in a spectacular setting, as if on a stage (Fig. 2).

Hasse's overtures to Sant'Elena from Dresden and Vienna seem to express the chance of a similar, double viewpoint.

As a conclusion: having reached his seventies, Hasse, with the 1771 Milan Ruggiero, left a fifty-year long career as opera composer. In his Viennese oratorios, he updated his style while keeping loyal to his own past, namely to the message his music had been spreading with remarkable coherence since the $1720 \mathrm{~s}$, showing an extremely rare, peculiar stylistic continuity which did not however exclude a significant modernization according to changing situations and contexts. Sant'Elena al Calvario and Il Cantico de'tre fanciulli show, in other words, a composer's metamorphic ability and availability in reconsidering his own successful works a quarter of a century after their birth, revising his own scores with a remarkable balance between economy of means and new resources and perspectives. Hasse's music keeps therefore perfectly recognizable in its peculiar features, while showing significant flexibility: a double quality which certainly contributed to no little extent to the composer's success and prompted those "far too generous and dear expressions" through which Salieri decided, on 22 December 1774, to "honour" Hasse's "small merit".

Raffaele Mellace (raffaele.mellace@unige.it), Università degli Studi di Genova.

\section{ABSTRACT \\ FROM COURT CHAPEL TO PUBLIC CONCERT: HASSE'S ORATORIOS FROM DRESDEN TO VIENNA}

In the early 1770 s J. A. Hasse proposed two of his oratorios, originally conceived for the Court Chapel of King August III in Dresden decades earlier, as productions of the Wiener Tonkünstlersozietät for the Kärntnertortheater. In Hasse's revision, major changes derive from both the changed stylistic connection and the different destination (audience, performers, space) of the oratorios. This specific case of authorial revision shows very clearly the potentials of metamorphosis of oratorio as a genre permanently positioned between Church and Theatre, Court and Town. 


\section{Key words}

oratorio, Dresden, Vienna, Kärntnertortheater

\section{Bibliography}

\section{Archival sources:}

Sant'Elena al Calvario, Dresden Version

Munich, Bayerische Staatsbibliothek, D-Mb, Mus. Ms. 237 (facsimile edition, "The Italian Oratorio 1650-1800" 28. New York: Garland, 1987).

Sant'Elena al Calvario, Viennese Version

Milan, Conservatorio "Giuseppe Verdi", I-Mc, MUSA. MS. 138.6

Il cantico de' tre fanciulli, Dresden Version

Dresden, Sächsische Landesbibliothek, Staats- und Universitätsbibliothek, D-Dl, Mus. 2477-D-8;

Vienna, Musiksammlung der Österreichischen Nationalbibliothek, A-Wn, S.M. 1047

Il cantico de' tre fanciulli, Viennese Version

Milan, Conservatorio “Giuseppe Verdi”, I-Mc, MUSA. MS. 135.3

\section{Literature:}

BELLINA, Anna Laura. La madre di Costantino, la vedova di Manasse e la nonna di Gioas. In Drammaturgia dell'oratorio. Metastasio, Hasse e il caso di "Sant'Elena al Calvario", Atti della giornata di studi musicologici, Faenza, 14 maggio 2005, ed. by Giovanni Tasso. Cesena: Edizioni Musigramma, 2006, p. 31-40.

GRENSER, Carl August. Geschichte der Musik hauptsächlich aber des großen Conzer- $u$. TheaterOrchesters in Leipzig (1840), ed. by Otto Werner Förster. Leipzig: Taurus Verlag, 2005.

HANSLICK, Eduard. Geschichte des Concertwesen in Wien. Wien: Braumüller, 1869.

HEARTZ, Daniel. Haydn, Mozart and the Viennese School. 1740-1780. New York-London: W. W. Norton, 1995.

KAMIEŃSKI, Łucjan. Die Oratorien von Johann Adolf Hasse. Leipzig: Breitkopf und Härtel, 1912.

KOCH, Michael. Die Oratorien Johann Adolf Hasses: Überlieferung und Struktur. Pfaffenweiler: Centaurus, 1989.

LANDMANN, Ortrun (ed. by), Katalog der Dresdener Hasse-Musikhandschriften, CD-Rom. Munich: RISM-Arbeitsgruppe Deutschland, 1999.

MELLACE, Raffaele. Johann Adolf Hasse. Palermo: L'Epos, 2004.

MELLACE Raffaele. Metastasio, Hasse e "Sant'Elena al Calvario": poesia e musica tra attesa e miracolo. In Drammaturgia dell'oratorio. Metastasio, Hasse e il caso di "Sant'Elena al Calvario", Atti della giornata di studi musicologici, Faenza, 14 maggio 2005, ed. by Giovanni Tasso. Cesena: Edizioni Musigramma, 2006, p. 13-29.

MELLACE, Raffaele. L'autunno del Metastasio. Gli ultimi drammi per musica di Johann Adolf Hasse. Florence: Olschki, 2007.

MELLACE, Raffaele. Article "Stefano Benedetto Pallavicino". In Dizionario Biografico degli Italiani, LXXVIII. Rome: Treccani, forthcoming.

METASTASIO, Pietro. Oratori sacri, ed. by Sabrina Stroppa. Venice: Marsilio, 1996.

OTTENBERG, Hans-Günter. Vom „Weltbürger“ zum Komponisten, der „den Kunstgesetzen seiner nordischen Heimath untreu“" wurde. Hasse-Studien, 2012, n. 7, p. 91-111.

RICE, John A. Hasse's Viennese Settings of Sant'Elena al Calvario and the Tonkünstler-Sozietät Oratorio of the 1770s. In Johann Adolf Hasse in seiner Zeit. Bericht über das Symposium vom 23. bis 26. März 1999 in Hamburg, ed. by R. Wiesend. Stuttgart: Carus-Verlag, 2006, p. 261-272.

Répertoire international des sources musicales. Einzeldrucke vor 1800, A/I/4, ed. By K. Schlager. Kassel: Bärenreiter, 1974. 
RYSZKA-KOMARNICKA, Anna. Johann Adolf Hasse e Pasquale Anfossi: "Sant'Elena al Calvario": tentativo di analisi comparativa. In Johann Adolf Hasse in seiner Epoche und in der Gegenwart. Studien zur Stil- und Quellenproblematik, ed. by Szymon Paczkowski and Alina Żórawska-Witkowska. Warszawa: Instytut Muzykologii Uniwersytetu Warszawskiego, 2002, p. 139-154.

STROPPA, Sabrina. "Fra notturni sereni". Le azioni sacre del Metastasio. Florence: Olschki, 1993.

VIARENGO, Alberto. L'oratorio „Il cantico de 'tre fanciulli “ di Johann Adolf Hasse: inquadramento storico, analisi; edizione critica. Diss. Univ. di Pavia, 1990/91.

ZENO, Apostolo. Epistolario scelto di Apostolo Zeno veneziano. Venice: Alvisopoli, 1829. 
